\title{
Comparative Analysis of Motorized and Manually Propelled Technologies of Artisanal Fisheries in Ijebu Waterside of Ogun State
}

\author{
Kareem, R. O. ${ }^{1}$, Idowu, E. O. ${ }^{2}$, Williams, S. B. ${ }^{2}$, Ayinde, I. A. ${ }^{1}$, \& Bashir, N. O. ${ }^{1}$ \\ ${ }^{1}$ Department of Economics and Actuarial Sciences, College of Social and Management Sciences, Crescent \\ University, Abeokuta, Ogun State, Nigeria \\ ${ }^{2}$ Obafemi Awolowo University, Ile-Ife, Osun State, Nigeria \\ Correspondence: Kareem, R. O, Department of Economics and Actuarial Sciences, College of Social and \\ Management Sciences, Crescent University, Abeokuta, Ogun State, Nigeria. E-mail: rskventures@yahoo.com
}

Received: July 9, 2012 Accepted: September 17, 2012 Online Published: November 20, 2012

doi:10.5539/sar.v2n1p133 URL: http://dx.doi.org/sar.v2n1p133

\begin{abstract}
This study was carried out to analyze the comparative analysis of efficiencies of artisanal fisheries in Ijebu Waterside of Ogun State. The objectives determined gross margin analysis; estimate the technical efficiencies of both the manually propelled technology (MPT) and motorized technology (MT) of artisanal fishery systems and determining the factors influencing the technical efficiencies of artisanal fisheries in the study area. A multistage sampling technique was used to select a total of 400 Artisans from the study area. Primary data were collected using structured questionnaire as interview guide, on the socio-economic characteristics, production inputs and output prices. The data collected were analyzed using both descriptive and inferential statistics. Stochastic production frontier model was used to estimate the technical, efficiencies of both motorized and manually propelled technologies in artisanal fishery system as well as the factors influencing the technical, efficiencies of the artisans.

The results of the comparison of the MPT and (MT) revealed that the average income per month for MPT was $\$ 361,847.48$ and the amount accruable per month for the MT was $\$ 560,755.57$. The results of the comparison of catch efficiency and inefficiency function showed that in MPT, fishing gear, vessel length, number of crew/skippers, quantity of bait and battery were all significant at 5 percent probability level while for MT, fishing gear, outboard engine, battery and miscellaneous quantity were the significant factors. The mean catch efficiency of MPT was 0.92 compared to MT with 0.98 . However, the comparison of the inefficiency shows that education, age, and household size are significant factors while education is significant factors in both MPT and MT respectively. The results of the returns-to-scale revealed that the parameters estimate of the MT was higher with 4.35 compared to MPT with 2.56 .
\end{abstract}

Keywords: comparative analysis, technical efficiencies, descriptive statistics, stochastic production frontier, artisanal fisheries

\section{Background to Study}

Nigeria as a developing country has expanding population both in the urban and rural areas. This has resulted in a significant imbalance between food production which lead to ever-increasing demand for Agricultural products especially fish and fish products. Hence, this imbalance in the supply of fish products has prompted about the efficient performance of fish output with particular reference to artisanal fishery system. Fish has the highest level of easily metabolisable proteins; it is reputed for its high quality proteins, fats, vitamins, calcium, iron and essential amino acids. The per caput consumption of animal protein in the country has been put at $5 \mathrm{gm}$ per day. This is far cry from FAO'S recommended level of $35 \mathrm{gm}$ per day (Afolami \& Oladimeji, 2003). Consumption of fish especially seafood products was reported to amount to approximately $14 \mathrm{~kg}$ per capita in developing countries in 2001 (Christopher et al., 2003). The more considerable and substantial contribution of fisheries worldwide is the supply of highly nutritious animal protein for human consumption and the employment and income generation in often remote coastal areas (Christopher et al., 2003).

Fish production is not only important as a source of food but also as a source of employment. Estimates showed that more than 25 million people are employed in artisanal or small-scale fisheries in sub Saharan Africa. Nigeria 
requires about 1.5 million tonnes of fish annually. This is what is needed to meet FAO's recommended minimum fish consumption rate of 12.5 Kilograms per head yearly to satisfy basic protein needs. For now, the unsatisfied demand will continue to be met through importation unless policy actions are geared towards improving domestic productions (Bada \& Rahji, 2010). Thus, developing fishing industry through efficient artisanal fisheries would drastically save much of the foreign exchange currently being used for the importation of fish and other fish products.

Artisanal fishery is composed largely of traditional fishermen who are about half a million in number scattered all over the country. Artisanal fishing is carried out with the use of traditional dugout boats (canoes) and other gear (traps). On a comparative basis, it is labour intensive and requires relatively low capital investment. It can thus, be described as a small-scale industry. Artisanal fishing activities are mostly in the shallow continental shelf (coastline), lagoons, creeks, rivers, lakes and reservoirs (Ajao, 2006).

Industrial fishery involves the use of large boats (trawlers) because operations are in the distant water (that is, mostly marine and deep sea). Therefore, it requires bigger and better equipped vessels, in contrast to the canoes used for artisanal fishery This distant water vessels are generally expensive and require high level organization with efficient shore-based facilities (such as berths for the trawlers and cold rooms for storage of products). Consequently, industrial fishery tends to be capital intensive.

A production process that uses more physical resources than an alternative method in producing a unit of output is thus said to be technically inefficient. However, since economic efficiency embodies both technical and allocative efficiencies, once the issues of technical inefficiency have been removed, the question of choosing between the set of technically efficient alternative methods of production, allocative efficiency, thus, comes to fore (Kirkley et al., 1995).

Knowledge of the efficiency level at both the firm and fleet level and its determinant factors are valuable information for understanding the problems of fisheries subsector of agriculture. However, such information would include measures of total economic efficiency. Technical efficiency can be measured by different techniques (e.g. Färe et al., 1994), but given the stochastic nature of fishing, the stochastic frontier approach has so far been advocated in the literature (Kirkley et al., 1995).

In Nigeria, per capita food production has steadily declined over the past five decades. Nigeria requires about 1.5 million tonnes of fish annually. This is what is needed to meet FAO's recommended minimum fish consumption rate of 12.5 Kilograms per head yearly to satisfy basic protein needs. For now, the unsatisfied demand will continue to be met through importation unless policy actions are geared towards improving domestic productions. In spite of the great potentials of fish farming in Nigeria, Nigeria is still unable to bridge the gap in the short fall between total domestic fish production and the total domestic demand. In Nigeria, total domestic fish production is far less than the total domestic demand (Agbede et al., 2003).

This could be attributed to the reliance on petroleum products in early $70 \mathrm{~s}$, and the shift of government's attention from the agricultural sector to the industrial sector. Thus, making the fisheries sub-sector of agriculture's contributions to the GDP to also decline drastically (FAO, 2003). However, the results of Table 1 shows that fishery output (tones) is the lowest when compared to other sub-sectors of agriculture. Hence, this calls for urgent need to address this low productivity with respect to recommending a better technology that will improve the level of efficiency in the state and the country at large.

Table 1. Major agricultural commodities ('000 tonnes)

\begin{tabular}{ccccccc}
\hline Sub sector of Agriculture & 2002 & 2003 & 2004 & 2005 & 2006 & 2007 \\
\hline Crop Production & 99813.6 & 106854.4 & 113591.6 & 121146.3 & 130574.1 & 129315.1 \\
Others Crops & 7886.2 & 8286.1 & 8896.1 & 9588.4 & 10103.5 & 110713.5 \\
Livestock Products & 2724.4 & 2940.4 & 3102.9 & 3260.3 & 3455.5 & 3647.3 \\
Fishing & 498.1 & 505.6 & 542 & 573.7 & 600.6 & 635.2 \\
Forestry('’000 cu metres) & 12762.3 & 129552.4 & 132275.3 & 1394857 & 141812.8 & 145593.1 \\
\hline
\end{tabular}

Source: Statistical Bulletin, Central Bank of Nigeria. 
The main objective of the study is therefore to compare the technical efficiency of both motorized and manually propelled technologies of artisanal fishery systems in Ijebu Water side of Ogun State, Nigeria. The specific objectives are to: analyze the gross margin analysis and estimate the technical efficiencies of different technologies and proffer possible recommendation with a view to increasing the level of productivity and efficiency in artisanal fisheries in the study area.

\section{Research Methodology}

A multistage sampling technique was used to select a total of 400 Artisans from the study area. The first stage was the purposive selection of the fishing zones. The second stage was also a purposive selection of 16 fishing communities that are more pronounced in fishing activities. For the third stage, in each of the 16 selected villages, 25 artisans were randomly selected from the list to make a total of four hundred (400) artisans.

Primary data were collected using structured questionnaire as interview guide, on the socio-economic characteristics, production inputs and output prices. The data collected were analyzed using both descriptive and inferential statistics. Gross margin analysis was used to determine the profitability of artisanal fishery enterprise. Stochastic production frontier model was used to estimate the technical, allocative and economic efficiencies of artisanal fishery system and the factors influencing the technical, allocative and economic efficiencies of the artisans.

Therefore, the stochastic frontier catch function for artisans in the study area is implicitly specified by:

$$
\mathrm{Q}=f\left(\mathrm{LNX}_{\mathrm{i}} ; \beta_{\mathrm{i}}\right) \exp ^{\text {(vi-ui) }}
$$

The equation (1) is thus linearised as stated below:

$\mathrm{LNCL}=\Phi_{\mathrm{o}}+\Phi_{1} \mathrm{LNFSGR}+\Phi_{2} \mathrm{LNVESSEL}+\Phi_{3} \mathrm{LNGRTHP}+\Phi_{4} \mathrm{LNCREW}+\Phi_{5} \mathrm{LNFUEL}+\Phi_{6} \mathrm{LNKERO}+$

$\Phi_{7} \mathrm{LNOIL}+\Phi_{8} \mathrm{LNBAIT}+\Phi_{9} \mathrm{LNFOOD}+\Phi_{10} \mathrm{LNBATRY}+\Phi_{11} \mathrm{LNMISC}+\mathrm{v}_{\mathrm{i}}-\mu_{\mathrm{I}}$

Where,

$\mathrm{CL}=$ Catch level (or fish catch) in $\mathrm{kg}$;

$\mathrm{FSGR}=$ Length of fishing gear in meters

VESSEL $=$ Size of vessel/canoe in meters

GRTHP $=$ Capacity of outboard engine (Horse power)

$\mathrm{CREW}=$ Number of crew/skippers per canoe per fishing trip

FUEL $=$ Fuel (petrol) in litres

$\mathrm{KERO}=$ Kerosene used in litres

OIL=Amount of oil used in the fish expedition

BAIT $=$ Number of baits used in the fish expedition

FOOD=Kilogram of food used in the fish expedition

BATRY=Number of battery used for torch-light during the fish expedition

MISC=Number of miscellaneous items which include plastic container, hand paddler etc)

$\Phi_{\mathrm{o}}=$ Constant terms

$\mathrm{LN}=$ Natural logarithm;

$\mathrm{v}_{\mathrm{i}}$ and $\mathrm{u}_{\mathrm{i}}$ are as earlier defined

\section{A priori expectation}

The variables included in the model include catch level in $\mathrm{kg}$, length of fishing gears in meters, vessel size in meters, capacity of outboard engine (Horse power), number of crews, amount of fuel consumed in litres, number of non-fishing activities, access to credit and miscellaneous in quantity. These variables were postulated to influence catch per unit effort (CPUE) (Akanni \& Akinwunmi, 2007).

\section{Results and Discussion}

\subsection{Distribution of Respondents by Tribe in Each Village of the Study Area}

Figure 2 shows the distribution of different tribes of the Artisans in the study area. The histogram shows that there are more of the Ilaje tribe in Igbosere, Olosumeta, JK Camp, Bolorunduro, Aba-Gold, Aba-Olori 
respectively. However, There are more of Ijebu tribe in Igbeki, Ilete, Oke-Oso, Ije-gbe, Oka, Isekun, Enuwaya, Akede, Mosafejo respectively while Ghanian tribe are not much pronounced in almost all the villages. This shows the proportion of the Ijebu tribe in the study area. This might be due to the fact that the populations of the study area are mainly Ijebu, in Ogun water side of the State.

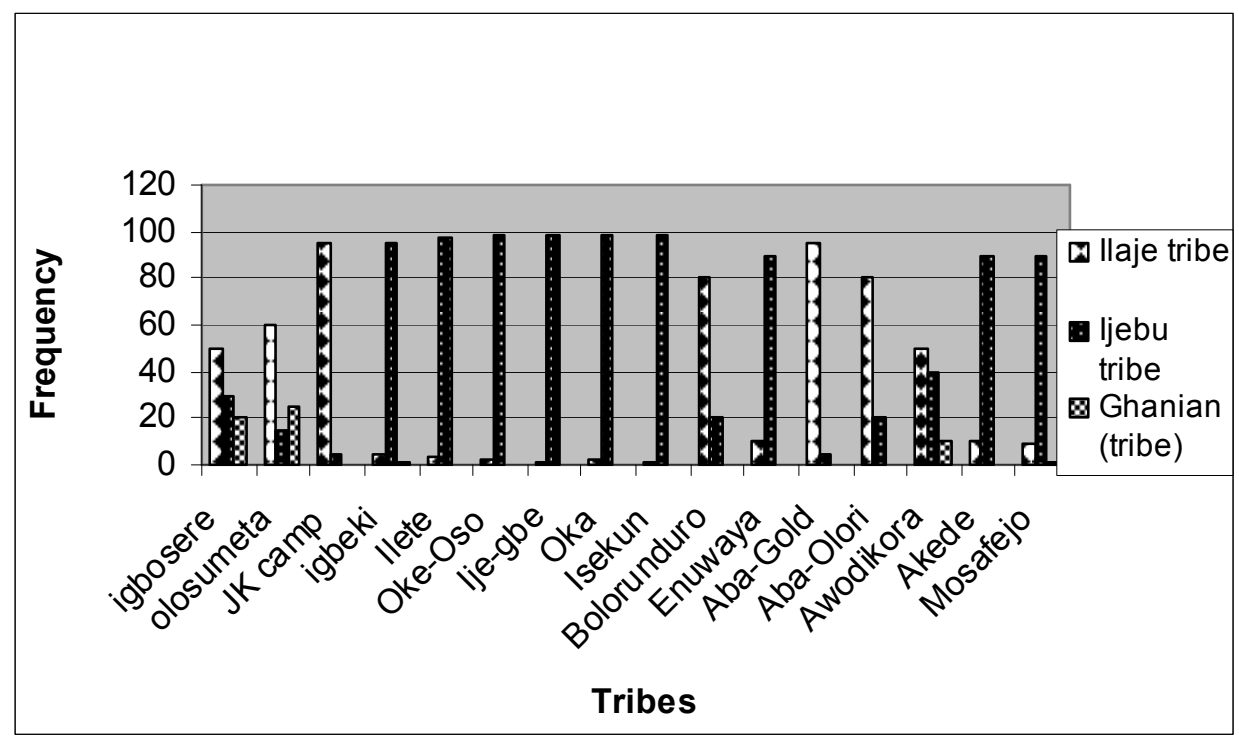

Figure 1. Distribution of respondents by tribe in each village of the study area

Table 2 shows the order of the most serious problem being encountered by the Artisans. Results reveals that lack of capital is the most serious problem (47.5\%), while the least is environmental (water hyacinth growth) with 7.1\%. This results is also in line with Raufu et al. (2009) opined that lack of fund/capital is one of the major problems encountered in fish business.

Table 2. Problems militating against the productivity of the artisanal fisheries

\begin{tabular}{lll}
\hline Items & Frequency & Percent \\
\hline Lackof capital & 114 & 47.5 \\
Lack of preservation equipment & 39 & 16.2 \\
Lack of facilities & 20 & 8.3 \\
High cost of fishing inputs & 26 & 10.8 \\
Infrastructure (i.e lack electricity, portable water) & 24 & 10.0 \\
Environment (water hyacinth) & 17 & 7.1 \\
Total & 240 & 100.0
\end{tabular}

Source: Data analysis, 2010.

\subsection{Comparison of the Gross Margin Analysis of the MPT and MT of An Average Fisher in the Study Area Per Year}

Table 3 shows the comparison of the gross margin analysis between the users of manually propelled technology (MPT) and the motorized technology (MT). The results revealed that the gross margin accruable to the MPT is $\$ 4,351,184.17$ (Four million, three hundred and fifty-one thousand, one hundred and eighty four naira and seventeen kobo) while $\$ 6,757,090.67$ (Six million, seven hundred and fifty seven thousand, ninety-six naira and sixty seven kobo) per annum respectively. 
Table 3. Comparison of the gross margin analysis of the MPT and MT of an average fisher in the study area per year

\begin{tabular}{|c|c|c|}
\hline \multirow[b]{3}{*}{ Output (catches from different species) (plus quantity consumed) } & \multicolumn{2}{|c|}{ Different technologies } \\
\hline & MPT & MT \\
\hline & 26,512 & 41136 \\
\hline Output Price/kg & $N 325.00 / \mathrm{kg}$ & $\$ 325.00 / \mathrm{kg}$ \\
\hline A. Revenue ( $\#)$ & $8,616,466.67$ & $13,368,509.09$ \\
\hline \multicolumn{3}{|l|}{ 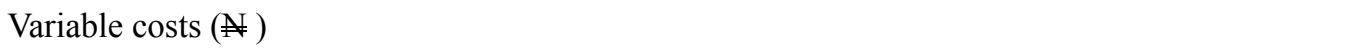 } \\
\hline Wage & $4,232,800.00$ & $6,544,200.00$ \\
\hline Fuel & 680.83 & $36,942.05$ \\
\hline Kerosene & $9,964.67$ & $7,974.55$ \\
\hline Cost of oil & $8,760.00$ & $9,621.82$ \\
\hline Cost of bait & 2352.00 & $2,420.18$ \\
\hline Cost of food & 7925.00 & $7,653.82$ \\
\hline Cost of battery & 2400.00 & $2,400.00$ \\
\hline Cost of maintenance/servicing & 400.00 & $1,200.00$ \\
\hline B. Total variable cost ( $¥)$ & $4,265,282.50$ & $6,612,412.42$ \\
\hline C. Gross margin ( & $4,351,184.17$ & $6,757,096.67$ \\
\hline \multicolumn{3}{|l|}{ Fixed costs (Depreciated cost) } \\
\hline Cost of fish gear & $2,280.71$ & $2,600.91$ \\
\hline Cost of vessel & 6610.19 & $7,175.30$ \\
\hline Cost of outboard engine & 0 & $18,169.51$ \\
\hline \multicolumn{3}{|l|}{ Cost of miscellaneous } \\
\hline \multicolumn{3}{|l|}{ (plastic/aluminum, weighing scale etc) } \\
\hline & 83.47 & 84.11 \\
\hline Cost of paddle & 40.00 & 0 \\
\hline D. Total fixed cost ( & 9014.37 & 28029.83 \\
\hline E. Total cost of operations( & $4,274,296.87$ & $6,640,422.25$ \\
\hline F. Average net profit/month( $(\mathbb{N})$ & $361,847.48$ & $560,755.57$ \\
\hline \multicolumn{3}{|l|}{ Profitability Indicators } \\
\hline Benefit-ratio analysis $(\mathrm{A} / \mathrm{E})$ & 2.015 & 2.013 \\
\hline Rate of return on investment $(\mathrm{F} / \mathrm{E})$ & $101.59 \%$ & $101.33 \%$ \\
\hline
\end{tabular}

Source: Data analysis, 2010.

N.B: Maintenance/Servicing includes the costs of servicing fishing gear, vessel/boats, outboardengines etc.

The table also shows the total variable costs of $\$ 4,265,282.50$ and $\$ 6,612,412.42$ for both MPT and MT per annum respectively. However, the average income per month for MPT is $\$ 361,847.48$ (Three hundred and sixty one thousand, eight hundred and forty-seven and forty-eight kobo) and the amount accruable per month for the MT is $\$ 560,755.57$ (Five hundred and sixty thousand, seven hundred and fifty-five naira and fifty-seven kobo). These results imply that the operators of motorized technology in fishing activities make more revenue and more profit compared to the artisans using manually propelled technology. These results might not be unconnected to the fact that Artisans who use motorized technology, have the advantage of covering more distant area along the coast for better catch of different fish species compared to the operators of the manually propelled technology. This corroborates the finding of Abowei and Hart (2008) and Anene et al. (2010) who reported a high net revenue of $\$ 161,444.52 /$ month in Oguta, Imo State, Nigeria. Though, the results did not compare the different 
technologies but this still emphasize the profitability of the artisanal fishery enterprises due to the unlimited access (open access) to fishing area by the Artisans in Nigeria.

Furthermore, the results of the comparison of the profitability indicators show that the benefit-cost ratio accruable to MT and MPT are both 2.013 and 2.015 respectively. These results indicate that for every N1.00 invested by an artisan would earn N2.013 with respect to MT while MPT yields N2.015. The results of this comparison is revealing the fact that though, the motorized has the better access to cover a long distance, it does not mean that the operators of motorized would not get there, hence, this is not a sufficient condition to be a better artisans or enhance their efficiency as the sea is an open access which often needs skill and experience at all times in the business. However, both technologies are profitable because of the B-C ratio that is greater than 1.

Similarly, the results of the rate of return to investment further depict the MT benefitted about $101.33 \%$ while MPT benefitted $101.55 \%$ from their investments. However, it shows that the MPT is better off with a difference of N0.23 (Twenty three kobo).

The contrary results to the economic theory of more productivity due to improved technology might be due to their years of experience or the level of education. Thus, the results do not provide evidence from the economic theory that improved technology enhances catch output. Hence, this may be due to lack of adequate knowledge about the operation of the MPT (Squires et al., 2002).

\subsection{Comparison of Catch Efficiency Model and Inefficiency Function of Manually Propelled Technology (MTP) and Motorized Technology (MP)}

The comparison of estimated technical efficiency models and inefficiency function of manually propelled and motorized technologies was done based on the hypothesis that the type of technology adopted would likely affect the level of technical efficiency level of the respondents artisans. The coefficients of the estimated technical efficiency are depicted by Table 4. It shows that among the eleven production variables considered in estimating the technical efficiency of manually propelled technology (MPT), all were found to be positive. In the case of motorized technology (MT), litres of kerosene used, oil, and bait were found to be negative. However, number of gear, vessel, engine, crew, fuel, food and battery used were found to be positive. Similarly, for MPT, gear, engine, crew bait, food and battery were all significant at 5 percent probability level. For MF, gear, vessel, engine, oil, battery and number of miscellaneous items were significant factors. The results are in agreement with Akanni (2008) though, used restricted probit parameters, found all the parameters estimated to be positive.

The inefficiency function of Table 4 shows that education, age, experience, distance from the sea to the fishing ground and gender to be positive, while education, age, household size, are the significant factors determining technical efficiency. However, the implication of the positive variable in the inefficiency function is opposite direction of the production variable. For instance, the more educated the artisan is, the less technical inefficient he would be in the catch per unit effort. This also corroborates Onumah et al. (2010) who reported that the combine effect of operational and farm specific factors (age, experience land, education etc) influence technical inefficiency of farmers.A critical examination of the motorized technology shows that all the variables are negative except education which was also significant at 10 percent. A sigma squared of MPT is 0.090 while MF is 0.078 . Though, both are significant at 5 percent probability level, it shows that the magnitude of variation is higher in MT compared to MPT. Similarly, gamma $(\gamma)$ value for MPT is 0.047 while MF has 0.943 . This is also higher in MF compared to MPT. It should be noted that gamma shows the amount of variation resulting from technical inefficiency of the artisans.

The mean technical efficiency of MPT is lower with 0.92 compared to MT of 0.98 . This implies that the technical efficiency of the motorized technology in higher than the manually propelled technology. This is, because it is expected that the MT artisans have the tendency to move faster and cover more distance on water which influence their fish catch level. This fact supports the findings of Akanni (2008) who found out that the mean Technical efficiency of motorized artisans (MF) was higher compared to manually propelled artisans (MPF). 
Table 4. Comparison of estimated catch efficiently model and inefficiently function of Manually Propelled Technology (MPT) and Motorized Technology (MT)

\begin{tabular}{lll}
\hline Production function variables & $\begin{array}{l}\text { MPT Technical } \\
\text { ML estimates }\end{array}$ & $\begin{array}{l}\text { MT Technical } \\
\text { ML estimates }\end{array}$ \\
\hline Intercept & $5.5049\left(5.6760^{*}\right.$ & $-5.413(-5.578)^{* *}$ \\
Ln Gear & $0.152\left(2.24930^{*}\right.$ & $0.12492 .666)^{*}$ \\
Ln Vessel & $0.078(0.400)$ & $0.136(1.135)$ \\
Ln Engine & $0.394(2.795)^{*}$ & $0.142(1.568)^{* *}$ \\
Ln Crew & $0.249(1.883)^{* *}$ & $0.056(0.587)$ \\
Ln Fuel & $0.036(0.941)$ & $0.024(0.165)$ \\
Ln Kerosene & $0.017(0.286)$ & $-0.017(-0.402)$ \\
Ln Oil & $0.051(3.097)^{*}$ & $-0.015(-1.202)$ \\
Ln Bait & $0.152(-1.308)$ & $-0.001(-0.008)$ \\
Ln Food & $0.222(1.354)$ & $0.013(0.109)$ \\
Ln Battery & $1.178(3.605)^{* *}$ & $4.196(11.716)^{*}$ \\
Ln Music & $0.033(0.154)$ & $-0.134(1.592)^{* *}$ \\
Inefficiency function & & \\
Intercept & $-6.697(-2.083)^{*}$ & $-0.0819(-0.0817)$ \\
Ln Education & $0.067(2.083)^{*}$ & $1.474(1.570)$ \\
Ln Age & $1.689(3.961)^{*}$ & $-0.460(-0.483)$ \\
Ln Experience & $0.150(0.532)$ & $-0.2279(-0.121)$ \\
Ln Trip & $-0.002(-0.009)$ & $-0.648(-0692)$ \\
Ln Household size & $-0.401(-1.804)^{*}$ & $-0.683(0.372)$ \\
Ln Distance & $0.296(0.7550$ & $-0.216(0.217)$ \\
Ln Gender & $0.000(0.000)$ & $-0.023(-0.029)$ \\
Ln Credit & $-2.738(-0.187)$ & $-0.0098(-0.0097)$ \\
Diagnosis Statistics & & \\
Sigma Square $\left(\sigma^{2} \mathrm{~s}=\sigma^{2} \mathrm{u}+\sigma^{2} \mathrm{v}\right)$ & $0.0904(3.274)^{*}$ & $0.0780(7.344)^{*}$ \\
Gamma $(\gamma)=\sigma^{2} \mathrm{u} / \sigma^{2} \mathrm{~s}$ & $0.0468(0.153)$ & $0.943(95.859)^{*}$ \\
Log likelihood function & 36.851 & $(27.025)$ \\
Number of Observation & 180 & 220 \\
Average TE & 0.923 & 0.984 \\
\hline 2010. & & \\
& & \\
& &
\end{tabular}

Source: Data analysis, 2010.

*significant at 5-percent probability level.

**significant at 10-percent probability level.

Values in parentheses are t-statistics.

N.B: $(\mathrm{P}<0.01=2.58 ; \mathrm{P}<0.05=1.64 ; \mathrm{P}<0.10=1.28)$.

3.4 Comparison of Elasticity's of Production and Returns to Scale of Manually Propelled and Motorized Technologies

The estimation of the elasticity of production and returns to scale is to compare the proportionate change in the output as a result of additional inputs used. The results are presented in Table 5. The regression coefficients in the Cobb-Douglas production function are the production elasticity and their sum indicates the returns to scale. 
Thus, the estimate which is greater than one implies increasing returns to scale. This shows that an increase in the use of some selected variables would results in more than proportionate increase in the frontier output. However, the results revealed that the production elasticity for each of the resources is less than unity for both MPT and MT indicating that the relationship between these resources and value of output is inelastic except for lnbattery. Similarly, the returns to scale derived from the summation of production elasticities showed the increasing returns to inputs used. The returns to scale parameters indicate that, MT value is higher with 4.35 compared to MPT with 2.56. The implication of this result is that, every addition to the producing inputs would lead to more than proportionate addition to the outputs. This assertion is also in agreement with Anene et al. (2010) and Edward et al. (2010).

Table 5. Comparison of elasticity's of production and returns to scale of manually propelled and motorized technologies

\begin{tabular}{ccc}
\hline Inputs & MPT elasticity's of production & MT elasticity's of production \\
\hline Ln Fishing gear & 0.152 & -0.124 \\
Ln Vessel & 0.394 & 0.136 \\
Ln Engine & 0.249 & 0.142 \\
Ln Crew & 0.036 & -0.024 \\
Ln Kerosene & 0.017 & -0.017 \\
Ln Oil & 0.051 & -0.015 \\
Ln Bait & 0.015 & -0.001 \\
Ln Food & 0.222 & 0.013 \\
Ln Battery & 1.178 & 4.196 \\
Ln Miscellaneous & 0.033 & -0.134 \\
Returns to scale & 2.56 & 4.35 \\
\hline
\end{tabular}

Source: Data analysis, 2010.

\subsection{Tests of Significant Differences of The Socio-Economic Variables of Manually Propelled and Motorized Technologies}

The variables investigated are educational attainment, age of respondents, years of experience in fishing, household size (number), and the level of profitability of artisans. The result is presented in Table 6 .

The results indicate that there were no significant differences between education of MPT and MF. Hence, the hypothesis was rejected. The results supported the findings of Adeokun et al. (2006) who found out that there were no significant relationships between age, education and adoption of innovation in artisanal fisheries in Ogun State, Nigeria. Also, result of years of age shows a significant difference. Years of experience and levels of profitability were also found to be significant at 1 percent and 10 percent respectively.

This result implies that there is significant difference in the years of experience and their level of profitability across the fishing technologies. The household size of the respondents across the fishing technologies was not significant. Hence, the null hypothesis (Ho) was accepted. This result implies that there is no significant difference in the household size of both the MPT and MF.

The results of t-test of significance difference between the economic efficiency of both MPT and MT also revealed that there is a significant difference at 1 percent level of probability. This thus confirms the earlier results of the canoe manually operated artisans being more economically efficient which might be due to lack of technical know-how of most artisans using motorized technology. This portends to the fact that technical-know how of the motorized will results in higher productivity. This means that there is a difference between the level of economic efficiency of both the MPT and MT technologies. This suggests that the MPT are more efficient when considering the application of the product of technical and allocative or price efficiency. Thus, the issue of technical know-how among the motorized artisans should be given high priority as it enhances technical and allocative efficiencies of the artisans in the study area. 
Table 6. Test of significant of differences of the socio-economic variables of manually propelled and motorized technologies

\begin{tabular}{|c|c|c|c|c|}
\hline Variables & Mean values & Level of significance & Significant & Decision \\
\hline \multicolumn{5}{|l|}{ Education } \\
\hline (MPT) & 7.95 & & & \\
\hline (MT) & 8.68 & 0.309 & NS & Accept Ho \\
\hline \multicolumn{5}{|l|}{ Age (years) } \\
\hline Manually propelled technology & 46.99 & & & \\
\hline Memorized technology & 47.49 & 0.000 & $* * *$ & Reject Ho \\
\hline \multicolumn{5}{|l|}{ Experience (years) } \\
\hline MPT & 21.59 & & & \\
\hline MT & 25.55 & 0.001 & $* * *$ & Reject Ho \\
\hline \multicolumn{5}{|l|}{ Household size } \\
\hline MPT & 5.34 & & & \\
\hline MT & 5.33 & -0.516 & NS & Accept Ho \\
\hline \multicolumn{5}{|l|}{ Profitability } \\
\hline MPT & $4.903 \mathrm{E} 6$ & & & \\
\hline MT & $6.262 \mathrm{E} 6$ & 0.077 & $*$ & Reject Ho \\
\hline \multicolumn{5}{|l|}{ Economic Efficiency } \\
\hline MPT & 0.8449 & & & \\
\hline MT & 0.8307 & 0.093 & * & Reject Ho \\
\hline
\end{tabular}

Source: Data analysis, 2010.

***: Test significant of 1 percent probability level.

*: Test significant at 10 percent probability level.

NS-: t- value not significant.

MPT: Manually propelled technology.

MT: Motorized technology.

\section{Conclusion and Recommendation}

The results of the comparison of the (MPT) and (MT) revealed that the gross margin accruable to the MPT was $\$ 4,351,184.17$ (Four million, three hundred and fifty-one thousand, one hundred and eighty four naira and seventeen kobo) while $\$ 6,757,090.67$ (Six million, seven hundred and fifty seven thousand, ninety-six naira and sixty seven kobo) per annum respectively. However, the average income per month for MPT was $\$ 361,847.48$ (Three hundred and sixty one thousand, eight hundred and forty-seven and forty-eight kobo) and the amount accruable per month for the MT was $\$ 560,755.57$ (Five hundred and sixty thousand, seven hundred and fifty-five naira and fifty-seven kobo). The results of the comparison of catch efficiency and inefficiency function showed that in MPT, fishing gear, vessel length, number of crew/skippers, quantity of bait and battery were all significant at 5 percent probability level while for MT, fishing gear, outboard engine, battery and miscellaneous quantity were the significant factors. The mean catch efficiency of MPT was 0.92 compared to MT with 0.98 . However, the comparison of the inefficiency shows that education, age, and household size are significant factors while education is significant factors in both MPT and MT respectively. The results of the returns-to-scale revealed that the parameters estimate of the MT was higher with 4.35 compared to MPT with 2.56. The result of the t-test analyzed found out that there was no significant difference in the education and household size of MPT and MT respondents. The age, years of experience and the level of profitability were found to be significantly different across the fishing technologies. The results of the hypothesis of the parameters of the stochastic production frontier and inefficiency function showed the null hypothesis (Ho) being rejected and alternative hypothesis accepted. The implication of this is that, there was an observed inefficiency among the 
artisans in the study area. Moreso, Cobb-Douglas function estimation showed that variables considered in both MPT and MT contributed to the fish output. Finally, the study concluded that there is significant difference in the age, years of experience and the level of profitability across the fishing technologies. The results also confirmed that there is a significance difference in the economic efficiency of both technologies. This study also revealed that there was an observed inefficiency among the artisans in the study area. Arising from the findings of this study, the following recommendations are proffered with a view to strengthening policies and for stake holders (artisans and government) to put in place appropriate measures that would enhance fishery sustainability in the study area and the country in general: The Nigerian government should subsidize the cost of fishing gear and other significant inputs in the model, especially the fishing gear and outboard engine that enhances catch per unit effort of the artisans; the Nigerian government should continually enhance the giving of technical advice to artisans on how best to use the various fishing technologies especially the outboard engine that is significant, for more productivity in the fishing business with a view to improving the inefficiency observed in both technologies in the study area; and the need for legislation on the open access (unlimited) fishing, arisen from excess profit accruable (profitability) to artisans in the study area through the enforcement of closed season to enhance species re-generation.

\section{References}

Adeokun, O. A., Adereti, F. O., \& Opele, A. I. (2006). Factors Influencing Adoption of Fisheries Innovations by Artisanal Fishermen in Coastal Areas of Ogun State, Nigeria. Journal of Applied Science Research, 2(2), 966-971.

Afolami, C. A ., \& Oladimeji. (2003). Producer Response to Retail Egg Price in Ogun State, Nigeria. Journal of Animal Production. 30(1), 81-86. http://dx.doi.org/10.4314/njap.v30i1.3317

Ajao, A. O. (2006). Economics of Fish Farming in Oyo State, Nigeria. An Unpublished PhD Thesis, Department of Agricultural Economics, Obafemi Awolowo University, Ile-Ife, Osun State, Nigeria, pp. 2-5.

Bada, T., \& Rahji, M. A. Y. (2010). Fish and Fish Marketing Problems in Ibadan, Nigeria. Journal of Agricultural Science, 2(3).

Christopher, L., B. W., Delgado, W. R., Mark, M., \& Mahfuzuddin, A. (2003). Fish to 2020: Supply and Demand in Changing Global Markets.pp. 10-20. International Food Policy Research Institute and Worldfish Center. Library of congress Cataloging-Publication Data.1-30.

FAO. (2005). Review of the state of world fishery resources in 2003: marine fisheries, by S.M. Garcia, I. De Leiva Moreno \& R.J.R. Grainger. FAO Fisheries Technical Paper No. 457. Rome.

Färe, R., Grosskopf, S., \& Lovell, C. A. K. (1994). Production Frontiers, Cambridge, Cambridge University Press.

Faturoti, E. O. (2010). Fisheries Contribute 126.4 Billion Naira To Nigeria Economy: Fish network. Fisheries Society of Nigeria Quarterly Publication. Vol.III, pp. 8-9.

Kirkley, J. D., Squires, D., \& Strand, I. (1995). Assessing Technical Efficiency in Commercial Fisheries: The Mid-Atlantic Sea Scallop Fishery. American Journal of Agricultural Economics, 77, 686-697. http://dx.doi.org/10.2307/1243235

Raufu, M. O., Adepoju, A. A., Salau, A. S., \& Orebiyi, A. O. (2009). Determinant of yield Performance in Small Scale Fish Farming in Alimosho Local Government Area of Lagos State. International Journal of Agricultural Economics and Rural Development, 2, 9-13.

Tobor, J. G., \& Ajayi, T. O. (1992). Current Management of Fishery Resources for Sustainable Development in Nigeria. NIOMR Technical Paper. No.77. p. 10

Tobor, J. G. (1994). A Fisheries Policy for Nigeria. FISON Tech. Paper. No. 97. p.8

Williams, S. B., \& Awoyomi, D. O. (1996). Fish As a Prime Mover of the Economic Life of Women in a Fishing Community. Proceeding of the IXth International Conference of the International Institute of Fisheries Economics and Trade (IIFET) Held Tromso, Norway, 8-11 July, 1998, pp. 277-285. 